\title{
URBAN EXPANSION AND LOSS OF AGRICULTURAL LAND IN UYO URBAN AREA: IMPLICATIONS FOR AGRICULTURAL BUSINESS \\ *Njungbwen, $\mathbf{E}^{1}$. Njungbwen, $\mathrm{A}^{2}$. \\ DOI: http://dx.doi.org/10.4314/ejesm.v4i4.9
}

Received November $8^{\text {th }} 2011$; accepted December $30^{\text {th }} 2011$

\begin{abstract}
Urban expansion in Uyo Urban Area was analyzed using aerial photographs taken from 1969 - 2001 which use was complemented with the Quick bird satellite imagery for 2004. The objectives of this study were to evaluate the urban expansion that had taken place in Uyo Urban Area over the periods of the study and to assess its influence on agricultural lands. The geographical information system (GIS) technology and field studies were applied to carry out this research. The analysis showed that Agricultural lands continually dropped in land area during the period while the built-up lands constantly rose. The built-up lands increased by 40.34\% between 1969 and 1978, 5.63\% between 1978 and 1988, and 111.45\% between 1988 and 2001 and 0.16\% between 2001 and 2004 at the expense of the agricultural land which fell by 0.33\% between 1969 and 1978, 2.24\% between 1978 and 1988, 58.03\% between 1988 and 2001 and 4.26\% between 2001 and 2004. Furthermore, between 1969/1978, the average annual rates of urban growth in Uyo Urban area were $4.48 \%, 0.56 \%$ between $1978 / 1988,8.57 \%$ between 1988/2001 and $0.05 \%$ between 2001/2004 while the average annual rates of loss of agricultural lands were $0.04 \%, 0.22 \%, 4.46 \%$ and $1.42 \%$. The largest quantity, percentage and average annual rates of gains or losses of land by the urban and the agricultural areas were made between 1988 and 2001. The loss of agricultural land brought in hunger and poverty in Uyo and boosted agricultural business in the neighbouring states.
\end{abstract}

Keywords: Urban, Expansion, urban Expansion, Agricultural Land, Home Garden, Agricultural Business

\section{Introduction}

Urban expansion involves the twin process of internal reorganization and outward expansion of the urban area (Lean, W) and B. Goodall 1977). It is caused by both the economic and non-economic factors.

Urban expansion appears to have direct effect on the available agricultural land in and around the urban area which in turn affects food supply to the city. Food security and increasing losses of agricultural lands have become an issue of global concern (Bender, 1997, Brown 1995, Crosson, 1997 and Gajraj, 1981). The continued increase in human population, a decrease in freshwater supplies, loss of croplands, and the changing global climate are all factors that may influence the ability of societies to sufficient food to feed the world's inhabitants. Global food security is further threatened by socioeconomic changes in China. Given its large and growing percentage of the global population, and the recent economic shift from agriculture to industry, China is fast

${ }^{1}$ Department of Estate Management, University of Uyo, P.M.B. 1017, Uyo, Akwa Ibom State, Nigeria.

${ }^{2}$ No. 42, Ikot Ekpene road, Uyo, Akwa Ibom State.

Corresponding email: njungbwen_ernest@yahoo.co.uk becoming a major food importer. In a globalised world economy, increases in food imports to China will affect all nations and could increases global food prices, creating political and social instability, particularly in the Third World countries (Brown 1995 and Reid 1998). If, as predicted, global demand for food doubles by the year 2030, the prospects of increasing food production to meet future demands will require more land and water, or significant increases in crop production. Food production in this century has increased because of advances in the use of fertilizers, irrigation and pesticides (Postel 1998 and Matson et al 1997). However, the rate of increase in food production has slowed in the last three decades, and concerns have developed over the long term sustainability and environmental consequences of the intensification of agricultural systems, (Matson et al., 1997).

Population growth and economic changes are two important factors influencing land use changes (Bilsborrow and Okoth-Ogendo 1992, Helmer 
2000, Lugo 1996 and Turner et al (1996) and the distribution and amount of available agricultural lands. In many countries where there have been a shift from an agrarian to an commercial/industrial economy, abandoned agricultural lands are often converted to urban uses.

The integration of remote sensing and geographic information systems (GIS) has been widely applied and recognized as a powerful and effective tool in detecting urban land use and land cover change (Ashbindu et al 2001). Satellite remote sensing collects multispectral, multiresolution and multi-temporal data and turns them into information valuable for understanding and monitoring urban land processes and for building urban land cover datasets. GIS technology provides a flexible environment for entering, analyzing and displaying digital data from various sources necessary for urban feature identification, change detection and database development. As a result, it became a handy tool that was applied to carry out this research.

Initially, Uyo was a small village with a dispersed settlement pattern typical of the area. Uyo later became a Local Government Headquarters in Cross River State, Nigeria. With the creation of Akwa Ibom State as a geo-political entity on $23^{\text {rd }}$ September 1987 , Uyo then assumed the status of a State Capital and has remained the state capital till date. This transformation brought about increase in population and human activities, land use dynamics and by extension urban expansion. This urban expansion/ growth affected various land uses in the city most especially the agricultural lands. In view of the above, it became necessary for this research on urban expansion and loss of agricultural land in uyo urban area and its implications for agricultural business.

\section{Study Area}

The study area (Uyo urban area), Akwa Ibom State, Nigeria, is located between $112,000 \mathrm{~m} \mathrm{~S}-$ $118,000 \mathrm{mN}$ ) and $604,000 \mathrm{~m}-610,000 \mathrm{~m} \mathrm{~W}$ in the UTM Zone 32. The Limit of Uyo Urban area as at 1989 covered an estimated radius of about $3 \mathrm{kms}$ and has a total area of about $60 \mathrm{~km}^{2}$. Presently, on the Longitude and Latitude basis, the area is located between latitude 4o59' and 5o04' $\mathrm{N}$ and Longitude $7 \mathrm{o}^{2} 3^{\prime}$ and $8 \mathrm{o} 00$ ' $\mathrm{E}$. Also, the area is located on an elevation of about 60.96 meters (2090ft), above sea level.

\section{Materials and Methods}

The remote sensing and the geographic information system (GIS) technology were applied in carrying out the land use and land cover analysis for Uyo Urban Area. The stepwise methodology followed in this analysis was careful examination of the satellite imagery, development of an interpretation key, plotting of the Uyo Urban area boundary, georeferencing of the digital data, interpretation of the data, collection of ground truth data, editing, finalizing of maps and extraction of the statistical data for the different land use and land cover types. This was as seen applied in the works of Singh and Loshali 2005, Gourmelon, et al., 2004, Laymon, 2003, Acevedo, et al., 2003, Geomatics International Inc. 1996 and Ashbindu et al., (2001).

The interpretation of the satellite imagery was onscreen using Arc View 3.2a software in a windows XP professional operating environment. This was possible because the imagery was digital. The correction of overshoots, under shoots was done using Arc/Info software. Topology was established among the lines and polygons and the coding of the various land uses was done using Arc View GIS 3.2a. Appropriate colors were given to the different land uses, layouts were developed for them and the final maps were produced. Quantitative data for the different land use types for the different time periods were then extracted.

Change detection analysis has been found to be an efficient method for discovering and monitoring the development trends or changes in a region (Woodwell et, al; 1984 and Williams, 1984). Change detection analysis was thus carried out in this study. This was calculated through simple subtraction of the previous inventory data from the current one and the rate of the changes was determined by calculating their respective percentage values.

A group discussion was organized between the research student, field officers, and the zonal Manager of AKADEP at the Uyo Zonal office by the Zonal Manager during their August bi-monthly forum during which relevant information on the current situation of agricultural activities in Uyo was collected. 


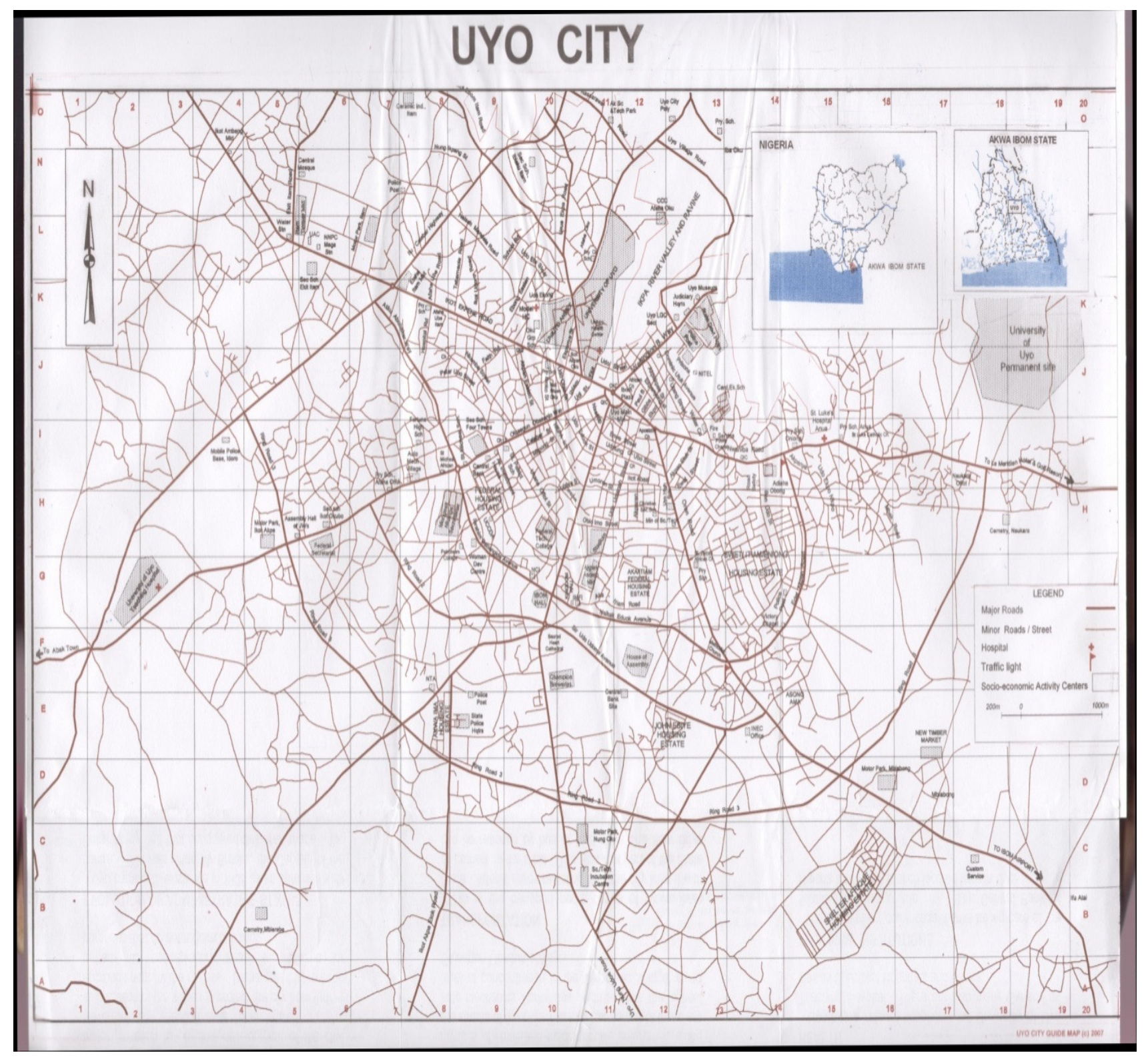

Fig. 1Map of study area

Source: Akwa Ibom State Ministry of Town Planning and Housing, 2008.

\section{Results and Discussion}

The results of the interpretation of aerial photographs and the satellite imagery were as given below: 


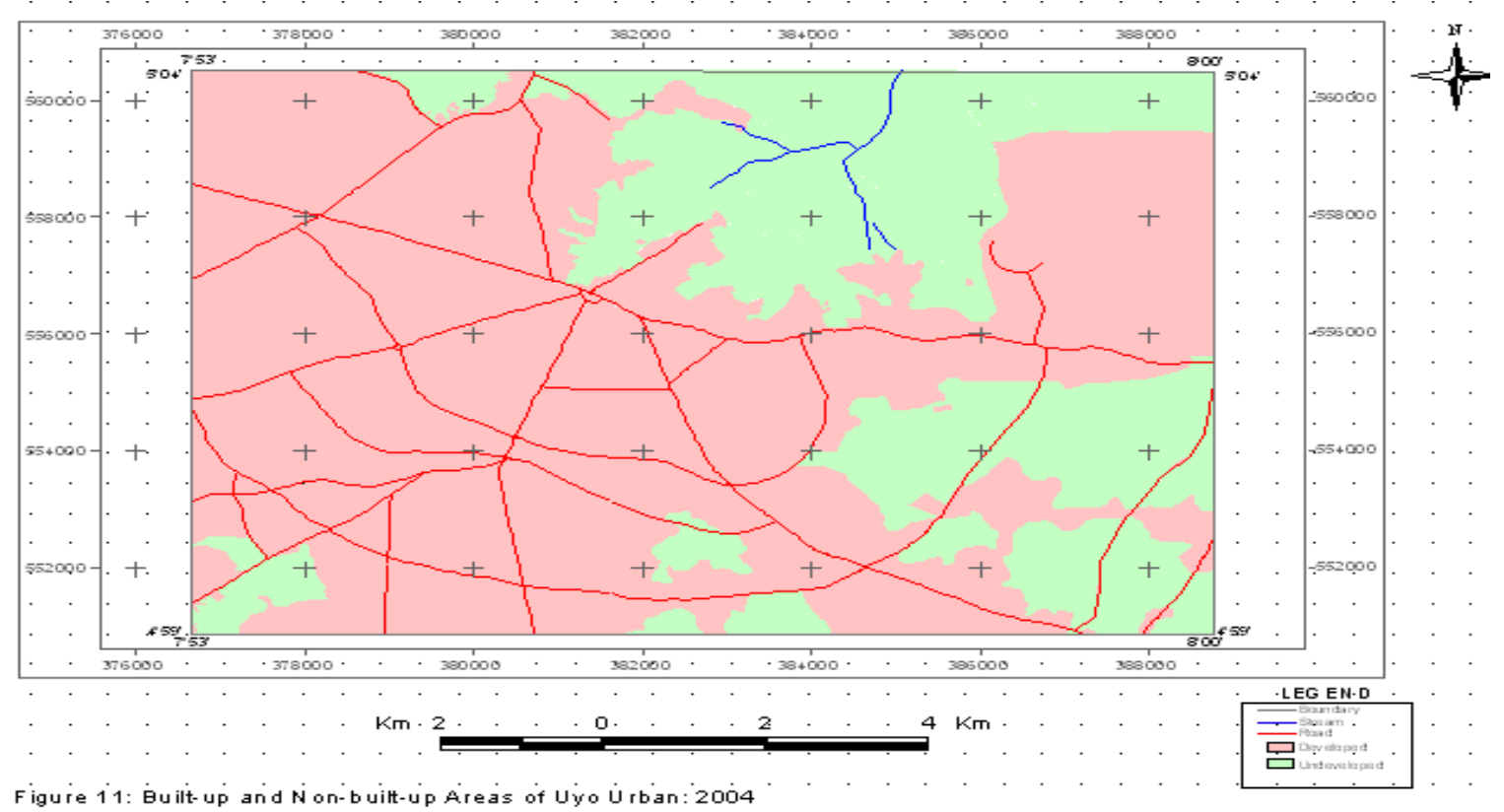

Figure 11: Built-up and Non-buitt-up Areas of Uyo Urban: 2004

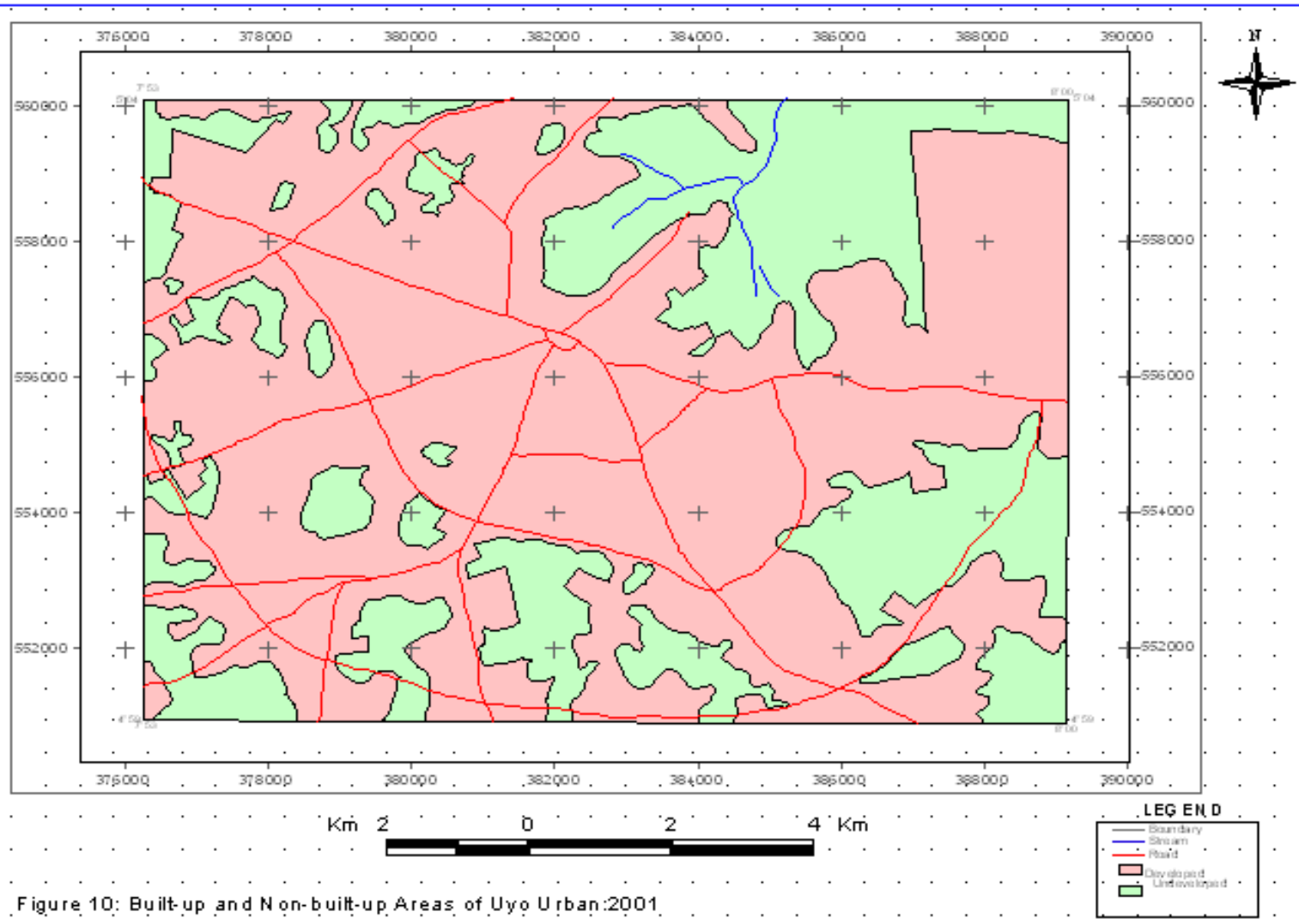



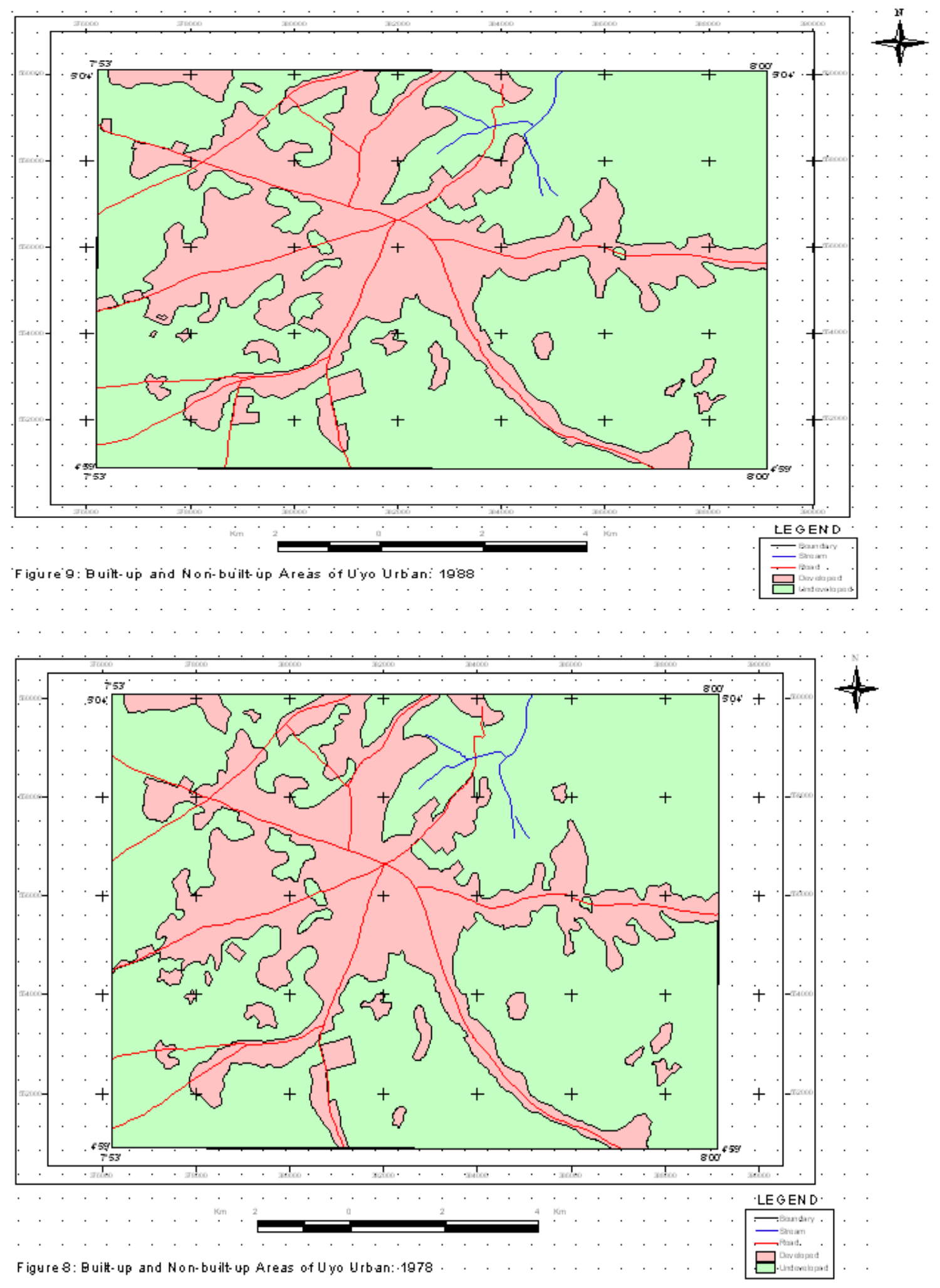




Table 1: Land Areas for Agricultural and Built-up Land for the periods.

\begin{tabular}{llllll}
\hline Landuse classes & 1969 & 1978 & 1988 & 2001 & 2004 \\
\cline { 2 - 6 } & & & $(\mathrm{ha})-$ & & \\
Agricultural & 6024.17 & 6004.58 & 5869.86 & 2463.78 & 2568.76 \\
Built-up & 2626.29 & 3685.62 & 3892.96 & 8231.59 & 8218.47
\end{tabular}

Source: Digitized Data from Aerial Photographs and the Quickbird Satellite Imagery by Author.

From the map and table (1) above, the built-up- areas kept on increasing from 1969 to 2001 and had a little drop in 2004. On the other hand, there was continuous loss of agricultural land from 1969 to 2001 and a small rise in agricultural land in 2004. 


\section{Table 2. Summary of Agricultural and Built-up landuse change statistics from 1969 - 2004}

The Quantity of land that was gained or lost and their respective percentage values for the various land use types

Land use 1969-1978\%

$1978-1988 \%$

1988-2001

$\%$

2001-2004

$\%$

Classes

Agriculture

$19.59 *$

$0.33 * 134.72 *$

$2.24 *$

$3463.08 *$

$58.03 * 104.98$

4.26

Built-Up

1059.33

$40.34 \quad 207.34$

$5.63 \quad 4338.63$

$111.4513 .12 *$

$0.16^{*}$

Source: Digitized Data from Aerial Photographs and the Quickbird Satellite Imagery by Author.

From table (2) above, the built-up- areas kept on having gains in land between1969-1978, 19781988, and 1988 to 2001 and had a little drop in land between2001-2004. The little drop in land here was accounted for by the different techniques that were applied in the interpretation of aerial photographs and the satellite imagery. The reverse was the case with agricultural land.

Table 3: Average annual rates of landuse change for the Agricultural and Built-up land for the compared periods.

\begin{tabular}{|l|c|c|c|c|}
\hline \multicolumn{1}{|c|}{$\begin{array}{c}\text { Land } \\
\text { use type }\end{array}$} & $\begin{array}{c}\mathbf{1 9 6 9 / 1 9 7 8} \\
\text { (ha) }\end{array}$ & $\begin{array}{c}\mathbf{1 9 7 8 / 1 9 8 8} \\
\text { (ha) }\end{array}$ & $\begin{array}{c}\mathbf{1 9 8 8 / 2 0 0 1} \\
\text { (ha) }\end{array}$ & $\mathbf{2 0 0 1 / 2 0 0 4}$ \\
\hline Agricultural & 0.04 & 0.22 & 4.46 & 1.42 \\
\hline $\begin{array}{l}\text { Built-up } \\
\text { land }\end{array}$ & 4.48 & 0.56 & 8.57 & 0.05 \\
\hline
\end{tabular}

Source: Digitized Data from Aerial Photographs and the Quickbird Satellite Imagery by Author. 
The average annual rates of changes in agricultural land and the built-up land all differed and the highest average annual rates of changes in agricultural land and the built-up land occurred between 1988 - 2001.

\section{Results from Farmers and ADP Staff on Urban Agricultural Activities}

Information was obtained from 71 farmers in Uyo Urban Area through questionnaires based interviews to know about their agricultural activities. The farmers were involved in crop production, animal production and both crop production and animal production. This constituted $60 \%, 13 \%$ and $27 \%$ respectively of the respondents. The various crops that were being produced included cassava, telfera occidentalis, okro, maize, cocoyam, melon, yam, plantain, water leaf, pepper, pawpaw, groundnut, fruits, coconuts, gnetum africanum, pineapple etc. Cassava and telfera occidentailis were the most popular crops produced. Goats, sheep, poultry, pigs, dogs, rabbits, fisheries and various combinations of the above animals were being produced in the urban area. It was noticed that poultry production was the most popular animal production activity in the town.

The wastes from both the animal and crop farmers were taken care of in the following ways: animal farmers sold their wastes to crop farmers, crop farmers sold their waste to animal farmers, some farmers dispose of their waste while majority made use of the wastes. This constituted $27 \%, 11 \%, 18 \%$ and $4 \%$ respectively of the respondents. Most farmers were of the view that farming helped them in household waste management. That was about $87 \%$ of the respondents.

Home garden owners were also interviewed and the research results revealed that a lot of home gardening and market gardening activities were going on in the face of the land hunger, poverty and the state of famine in the town. Intensive market gardening was going on around the prison, Nigerian telecommunication (NITEL) premises and other pieces of land around the town and within the ravine area. This was mainly for income to the urban families. The production was all year round as there was regular supply of pipe borne water on the sites particularly the Prison area.
It was observed that home gardens were available in the peri-urban, the government residential areas (GRA) and the urban areas of Uyo town. This was as confirmed by Akobundu et al (1992) in their home gardens study in South Eastern Nigeria. To be able to improve food supply and nutrient in take by urban families, there was need for incentives to home garden farmers in Uyo and education and training for them. Landauer and Brazil (1990) have recommended that such incentives be carefully designed which maximized self help and are adapted to local conditions and the perceptions of the people who actually design and manage tropical home garden (THG).

Irrespective of all the agricultural activities that were going on in Uyo, there was still food shortage due to low output form the farms, high prices of agricultural products and urban hunger and poverty. As a result, more food was usually supplied from other local government areas, rural areas and neighbouring states.

The result from ADP staff and farmers doing urban agriculture in Uyo revealed that the survival of urban agriculture in Uyo will depend on three things: that is specific legislation, which will guarantee land tenure for urban agriculture; a cohesive, organized network of vegetable producers and other producers of agricultural product in Uyo urban area; and high senstitization to get land owning families in Uyo to get actively involved in home gardening. This will go a long way to improve food production, reduce prices of agricultural products and reduce if not eliminate urban hunger and poverty. Waste re-use urban agriculture farming (WRUF) was being practiced at Uyo as additional nutrient source to urban agriculture. There was need for this practice to be encouraged. This was as had been recommended by Drechsel et al (1999) and Asomani and Haight (1999). Also, peri urban and urban vegetable production and other foodstuffs were playing a multiple role in achieving the Millennium Development goals of food security and reduction of malnutrition, job opportunities, poverty alleviation and support for women. Thus, this needed strong support and encouragement from the state Government and organized community action in the state. 


\section{Conclusions}

In this study, an integrated approach of remote sensing and GIS was developed for evaluation of rapid urban expansion and loss of agricultural land. Results revealed a notable increase in urban land use / cover between 1969 and 2004. Built-up areas has increased in all directions but for the Northern part of the city which was limited by the ravine.

Finally, although urban expansion cannot be stopped, with proper management and planning it can be directed in a desirable and sustainable way by protecting fertile agricultural land and ecological areas, creating green belt for the city. Though a lot of agricultural land had been lost as a result of urban expansion, a lot of agricultural business was still going on in the city. This contributed a lot to reduce hunger and food prices in the town though much food was still being imported from other local governments and neighbouring states.

\section{References}

Acevedo, W., Gaydos, L., Tilley, J., Mladinich, C., Buchanan, J., Blauer, S., Kruger, K. and

Schubert, J.(2003). Urban land use Change in the Las Vegas Valley. U.S. Geological Survey, Johnson Controls World Services (1-5). Retrieved March $\quad 25^{\text {th }}, \quad 2004$ from Http://geochange.er.usgs.gov/sw/changes/anthropo genic/population/las vegas/

Akobundu, E.N.T.,Obiefuna, J.C. and Meregini, A.O. (1992). Home Gardens of South- Eastern

Nigeria. UNU/INRA Programme: Project No. 92/057A. 51 pages.

Akwa Ibom State, (1989). Uyo Master Plan, Akwa Ibom State Government, Uyo.

Ashbindu Singh, H.S., Foresman, T. and Eugene, A. F.,( 2001). Status of World's Remainning closed Forests: An Assessment using Satellite Data and Policy Options. AMBIO. A Journal of the Human Environment, Vol.XXX No.1, 67-69.

Asomani, R and Haight, M.(1999). Rensing Organic Waste in Urban farming in African cities: A challenge for Urban Planners. In: Olanrewaju, B.S. (ed). Urban Agriculture in West Africa, contribution to food securityand urban sanitation. International Development Center, Ottawa and Technical center for Agriculture and Rural Cooperation, Wageningen, pp. 138-154.
Bender, W.H. 1997. How much food we will need in $21^{\text {st }}$ Century? Environment 39, 7-11.

(Bilsborrow, R.E. and Okoth-Ogendo, H.W.O. (1992). Population driven changes in land use Developing countries. Ambio 21, 37- 45.

Brown, L. R.1995. Who Will Feed China? W. W. Norton and Company, New York, New York, U.S.A.

Crosson, P. 1997. Will erosion threaten agricultural productivity? Environment 39, 4-31

Drechsel, P., Quansah, C., and Penning De, F. Vries, F. (1999). Urban and Peri-urban Agriculture in West Africa. Characteristics, Challenges and need for Action. In: Olanrewaju, B.S. (ed). Urban Agriculture in West Africa, Contribution to food security and urban sanitation. International Development Center, Ottawa and Technical Center for Agriculture and Rural Co-operation, Wageningen, pp. 138-154.

Gajraj, A.M. 1981. Threats to the terrestrial resources of the Caribean. Ambio 10,307-311.

Geomatics International Inc., (1996). The assessment of landuse and vegetation changes in Nigeria between 1978 - 1993/95. Forest Resource Management Evaluation and Consultancy Unit, Ibadan.

Gourmelon, F., Bioret, F.R. and Le Berre, I., (2004). Historic Land Use Changes and Implications for Management in a small protected island at Ushant, France, Patuxent Wildlife Research Centre,USGS.

Helmer, E.H. (2000). The landscape ecology of secondary tropical forest in montane Costa Rica. Ecosystems 3, 58-114.

Landauer, K. and Brazil, M. (1990). Tropical Home Gardens. United Nations University Press, Tokyo, pp. 257.

Laymon,C.,( 2003). Satellite Remote Sensing of land use change in Madison County. IN: Map

World, Directions Magazine.

Lean, W. and Goodall, B. (1977). Aspects of Land Economics. The Estate Gazette Limited,

151 Warder Street- London.

Lugo, A.E. ( 1996). Caribean island landscape: indicatives of the effect of economic growth in the region. Envir. Dev.Ecos 1,128- 136.

Matson, P. A., Parton, W.J., Power, A. G. and Swift, M.J. 1997. Agricultural intensification and Ecosystem properties. Science 277, 504-509.

Postel, S. L. (1998). Water for food production: Will there be enough for 2025? BioScience, 
48, 629-637

Reid, T. R. 1998. Feeding the Planet: Nail. Geogr. 4, 56-74.

Singh, A. and Loshali, D. C. (2005). Land Use Mapping in kotla Khad using Remote Sensing Technique. Environment \& Ecology 23(1): 7-12. Turner, M.G., Wear, D.N. and Flamm, R.O. (1996). Land ownership and land cover change in the southern Appalacian highlands and the Olympic peninsula. Ecol. Applic 6, 1150-1172 Williams, J.H. (1984). Forestry, Remote Sensing and the Monitoring of Change. University College of North Wales, p. 47. Department of Forestry and Wood Science.

Woodwell, G.M., Hobbie, J.E., Houghton, R.A.; Melillo, J.M.; More, B.; Park, A.B.; Peterson, B.J.; Sharer, G.R. (1984). Measurement of Changes in the Vegetation of the Earth by Satellite Imagery. In: Woodwell, G.M. (ed), the Role of Terrestrial Vegetation in the Global Carbon Circle: Measurement by Remote Scope Report 23. Wiley, New York. 